\title{
Landscape Changes and Fragmentation Analysis in a Guinea Savannah Ecosystem: Case study of Talensi and Nabdam Districts of the Upper East region, Ghana
}

\author{
Steve Ampofo ${ }^{1}$, Isaac Sackey ${ }^{2} \&$ Boateng Ampadu $^{1}$ \\ ${ }^{1}$ Department of Earth and Environmental Sciences, University for Development Studies (UDS), Ghana \\ ${ }^{2}$ Department of Applied Biology, University for Development Studies (UDS), Ghana \\ Correspondence: Steve Ampofo, Faculty of Applied Sciences (FAS), University for Development Studies (UDS), \\ P. O. Box 24, Navrongo, Ghana. Tel: 233-244-521-359. E-mail: sampofo@uds.edu.gh
}

Received: August 2, 2015

Accepted: August 24, 2015

Online Published: February 24, 2016

doi:10.5539/jgg.v8n1p41

URL: http://dx.doi.org/10.5539/jgg.v8n1p41

\begin{abstract}
Landcover change is an observed natural change dynamics at both the local and regional levels. However, its scales are exacerbated by human interaction with its natural environment. The study examines these spatio-temporal changes in landcover and the level to which the change is accompanied by fragmentation of the identifiable cover types in the Talensi and Nabdam districts in Northern Ghana. The research uses digital classification of Landsat satellite imagery for 1999 and 2007 to produce the cover types which results in good accuracy levels of $66.39 \%$ and $63.03 \%$ respectively. Fragmentation analysis of the landscape was computed using FRAGSTATS ${ }^{\circ}$ software for categorical maps obtained from the classified landcover maps for the two years. All cover types increased marginally. However, Bare areas decreased by as much as $17.17 \%$ and that of water decreased from $3 \%$ to $1 \%$. The changing landscape involving conversions within and among various cover types is accompanied by fragmentation in all classes but more pronounced in the Bare class. The Bare class type which has more patches corresponds to the class with increased cover size and rather strangely decreases in the mean path size.
\end{abstract}

Keywords: Fragmentation, Landscape, Landcover/landuse change, Patches, Class

\section{Introduction}

The presence of humans on earth and their interaction with nature is constantly changing landscapes and is having a great effect on the natural environment. The changes in landscapes are in response to socio-economic development such as agriculture, mining, logging and construction. These are primary components of many current environmental concerns of land use and land cover changes (Hong, 1999). Land use/land cover change is gaining recognition as a key driver of environmental change. Concerns about land use/land cover change emerged in the research agenda on global environmental change several decades ago with the realisation that land surface processes influence climate (Southworth and Munroe, 2004). Changes in land cover can be attributed to natural factors such as change in climatic conditions and geomorphologic processes for instance earthquakes and volcanoes (Alves and Skole, 1996). In recent times, although natural factors contribute to land cover changes, the interaction of humans with the natural environment to improve livelihoods, have transformed land use and consequently land cover (Ampofo et al., 2015).

Land cover change and landscape fragmentation in the Talensi and Nabdam Districts in Ghana is occurring as a result of anthropogenic activities. Change in land cover of natural landscapes to satisfy human needs is one of the apparent modifications resulting from human activities (Bizimana et al., 2004). Talensi and Nabdam Districts are found to be in a fragile ecology prone to perennial bushfires and other high socio-economic extractions despite its enormous and varied natural resources endowments like vast large tracts of arable land for cropping and rangelands, rock and mineral deposits, forest reserves, and rivers. However, these rich resources are being adversely impacted upon by anthropogenic activities, particularly mining, logging (Frimpong, 2011), poor farming practices and expansion (Vogt et al., 2007; Bizimana, 2004), quarrying, road transport infrastructure development (Seiler et al., 2006) leading to a potentially irreversible land cover change and fragmentation of landscapes (Talensi-Nabdam District SEA, 2012). 
Landscape fragmentation is a product of the interaction between ecological and socio-economic processes and cannot be ignored in the process of enumerating the effects of land use/land cover (LULC) change. Humans have actively managed and transformed the world's landscape for millennia (Ampofo, 2008; Bizimana, 2004). Population growth and migration to areas deemed favourable for agriculture is a major concern in tropical regions worldwide because of the resultant deforestation and landscape fragmentation (Berry et al., 1994).

The consequence of landscape fragmentation is a heterogeneous landscape, composed of smaller and isolated patches of habitats within a matrix less suitable for species that lived there originally (Fariq, 2003; Berry et al., 1996). A good understanding of the causes and effects of land use/land cover change and landscape fragmentation will help policy makers gain insight into the issues that contributes to the problem and decide which management practices should be instituted to improve on landscape ecology. According to Dwivedi \& Sreenivas. (2005) and Honnay et al. (2003), fragmentation of land and such corresponding potential threats as global climatic change, land use dynamics, change in biogeochemical cycles, and loss of habitats and biodiversity have currently become a central issue. This paper therefore investigates the dynamics of landcover change using multi-temporal Landsat satellite imagery. Specifically, the paper evaluates landscape change in terms of the proportions and fragmentation using various indices, this is done to reveal the pattern and specific areas of change for land management purpose.

\section{Materials and Methods}

\subsection{Study Area}

Talensi and Nabdam Districts, with Tongo and Nangode as capitals, respectively, are newly created districts which were carved from the erstwhile Talensi-Nabdam District which was also carved from the Bolgatanga Municipality which has Bolgatanga as its capital and the regional seat of administration. The districts are bordered to the North by the Bolgatanga District, South by the West and East Mamprusi Districts, Kassena-Nankana District to the West and the Bawku West District to the East.

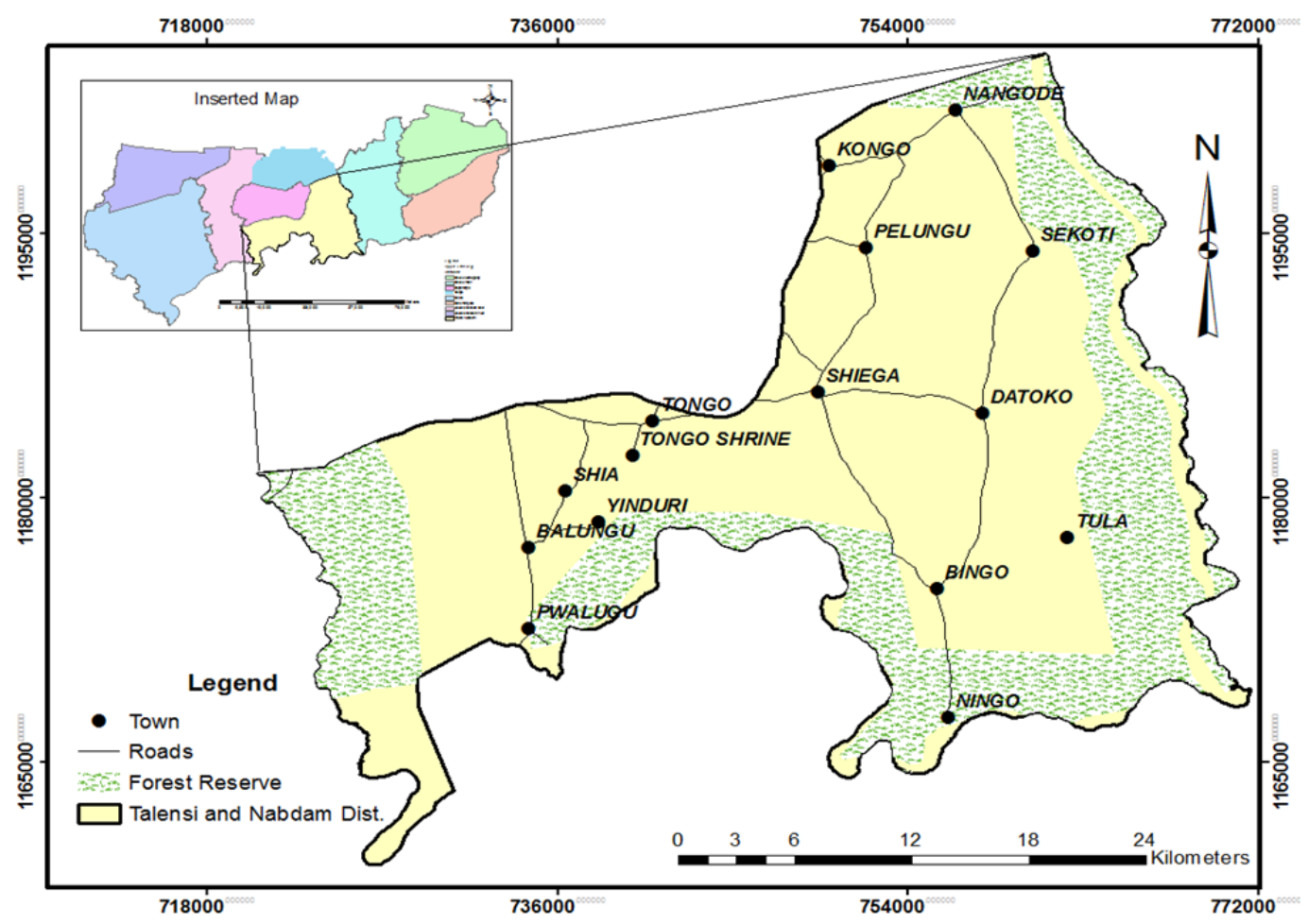

Figure 1. Map of Upper East Region of Ghana showing the location map of the study areas

\subsubsection{Topography and Drainage}

The districts have gentle slopes ranging from $1 \%$ to $5 \%$ gradient with some isolated quartzite and gneiss rock formations along some hilly terrain which have upland slopes of about $10 \%$ at the Tongo and Nangodi areas. The districts are drained mainly by the Red and White Volta and their tributaries. These physical characters have given rise to dry season farming activities along some parts of the Volta basin stretches of the districts. Similarly, 
the existence of mineral deposits has resulted in the proliferation of small scale artisanal mining activities in the districts and the rock outcrops have also resulted in the establishment of quarries.

\subsubsection{Climate}

The climate is classified as tropical, and has two distinct seasons, a wet rainy season, which is erratic, and runs from May to October, and a long dry season that stretches from October to April with hardly any rains. The mean monthly rainfall ranges between $88 \mathrm{~mm}$ and $110 \mathrm{~mm}$ and a mean annual rainfall of $950 \mathrm{~mm}$. The area experiences a maximum temperature of $45^{\circ} \mathrm{C}$ in March and April and a minimum of $12^{\circ} \mathrm{C}$ in December (Talensi-Nabdam District Profile, 2011).

\subsubsection{Forest and Ecosystem}

The vegetation is guinea savannah woodland consisting of short, widely spread deciduous trees and a ground flora of grass, which gets burnt by fire or the scorching sun during the long dry season. The extreme temperatures and prolonged dry season facilitate bush burning which affects tree recruitment and survival processes and promote land degradation (Talensi-Nabdam District Profile, 2011). The major savanna forest cover types in the districts are usually classified based on whether the savanna is closed or open, cultivated or riverine, grassland and the tree density per hectare. These results in the following discernible categories (Figure 2):

Closed cultivated savanna woodland $(<20$ trees/ha)

Grass/herb/without scattered trees (0-5 trees/ha)

Grassland with/without scattered tree/shrub

Open cultivated savanna woodland (11-20 trees/ha)

Open savanna woodland $(<25$ trees/ha)

Riverine savanna vegetation

Widely open cultivated savanna woodland (6-10 trees/ha)

The riverine savanna vegetation is mostly found along the channels of the White Volta and Red Volta rivers and other low lying areas such as dam sites and natural depressions which accumulate water. On the vast expanse of rocky hills that traverses the districts are grassland, shrub and very few isolated trees, particularly on the range of hills referred to as Tongo hills.

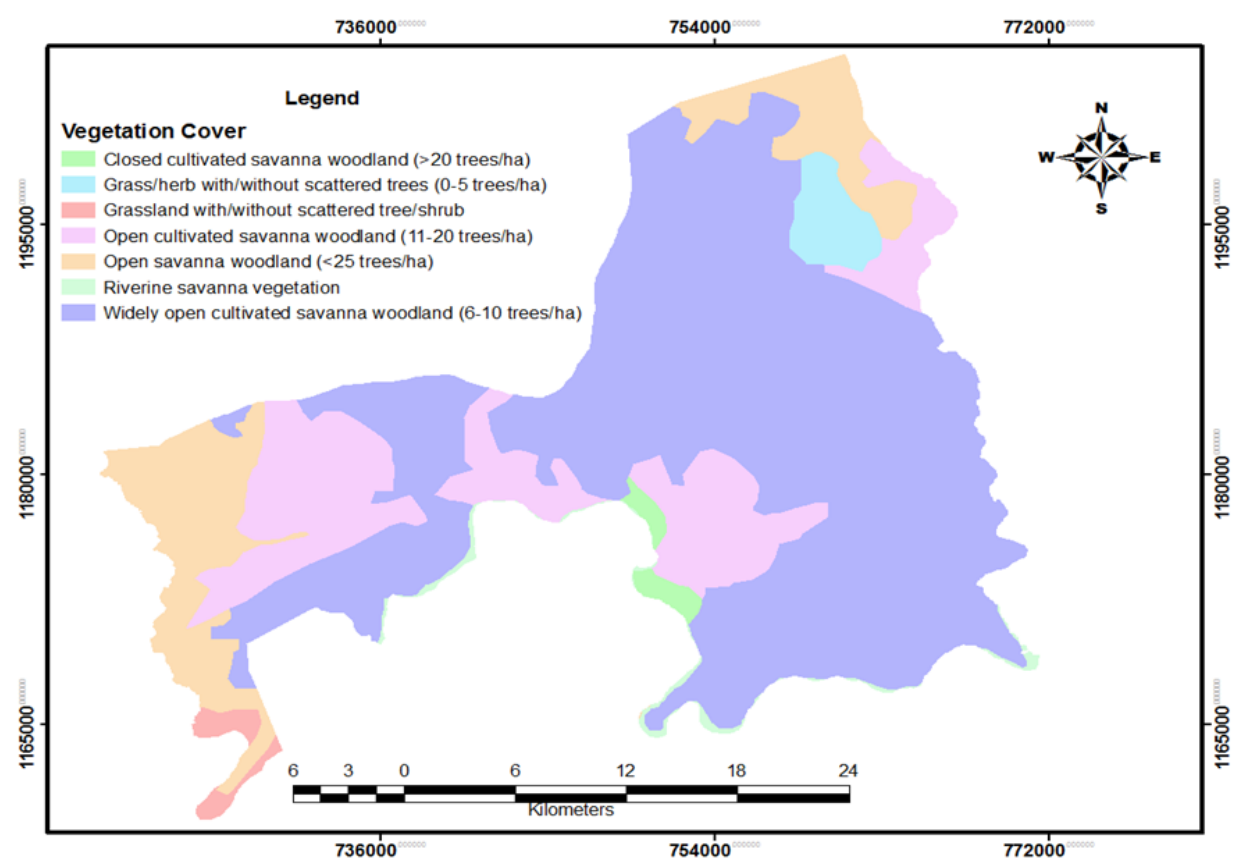

Figure 2. Vegetation map of the Talensi and Nabdam Districts

The natural environment is fairly degraded as it faces threat of severe drought with high temperatures and perennial outbreak of bush fires. It is evident that high population densities (especially in towns) with high demand for land for constructional activities, extensive cultivation, over-grazing, erratic rainfall and the extent of 
devastation do affect the natural environment thereby exposing it to desertification (Talensi-Nabdam District Profile, 2011).

\subsection{Materials}

The research is basically an analysis of spatial change; a pattern and trend analysis involving the use of multi-temporal Landsat satellite imagery. Landsat images of 1999 and 2007 with the same sensor and pixel resolution were used. The research materials used in this study and their characteristics are listed in Table 1.

Table 1. Satellite imagery and their acquisition dates

\begin{tabular}{llll}
\hline Satellite/sensors & Acquisition Date & Spatial Res.(M) & Remarks \\
\hline Landsat TM & $9^{\text {th }}$ December, 1999 & 30 & Dry Season \\
Landsat ETM & $5^{\text {th }}$ January, 2007 & 30 & Dry Season \\
\hline
\end{tabular}

The processing of the satellite imagery was carried out using the ERDAS Imagine(C) software version 9.1. Some specific image processing operations were done using the ArcGIS ${ }^{\circledR}$ software version 10.1, while some fragmentation statistics of the land use/land cover types were computed using Fragstats ${ }^{\circledR}$ software version 3.3. However, Microsoft Office ${ }^{\circledR}$ Suite version 2010 and Microsoft Visio ${ }^{\circledR}$ version 2007 were used for data input and graphical representation.

\subsection{Methods}

\subsubsection{Sampling Techniques}

Stratified random sampling was employed to collect field data with an approximately equal sample size in each land cover class. In each stratum, a simple random sampling was used to collect training and accuracy assessment samples, which were used for the classification and the validation of the classification accuracy respectively. Global Positioning System (GPS) readings were used to record the training and validation samples representative of all identifiable cover types. All the data were stored as ArcMap shapefiles and used later in the data analysis process for the extraction of image spectra from the multi-spectral datasets (Ampofo et al., 2015; Frimpong, 2011).

During the data collection, the distributions of the Ground Control Points (GCPs) were taken into consideration and small sample points (GPS points) of a land use/land cover type were randomly selected in the field. This was done throughout the study area by moving around the feature with the GPS instrument and a total of 238 samples were collected and used for the study. Half of the GPS sample points (119) were used for classification and the remaining points were used for accuracy assessment. Topographic maps and a Global Positioning System (GPS) receiver were used to find the location of the GCPs in the field. The geographic co-ordinates of the observation sites from the GPS reading were recorded at an accuracy of $\pm 3 \mathrm{~m}$.

\subsubsection{Image Acquisition and Processing}

Both Landsat Thematic Mapper (TM) and Enhanced Thematic Mapper (ETM) satellite images of the study area captured on $11^{\text {th }}$ January 1999 and $24^{\text {th }}$ February 2007, respectively, and having a spatial resolution of $30 \mathrm{~m}$ were acquired from the USGS global Visualisation site and processed. The satellite images selected and used were dry season images captured between the months of December and February. This was because of the difficulty in obtaining cloud-free images in the rainy season in tropical regions. It also meant that data on cover types in the cropping season were not captured as accurately as possible (Ampofo et al., 2015).

\subsubsection{Image Geo-referencing}

The Landsat ETM 1999 image was geo-referenced using GCPs collected in the dry season and this was used for an image-to-image registration of the other image using the same Area of Interest (AOI). This resulted in the same Root Mean Square Error (RMSE) of 0.015 a pixel. The following national topographic map projection properties were used for the geo-referencing:

Projection: Transverse Mercator

Datum: D_WGS_1984

Central Meridian: -3.000000

Scale factor at central meridian: 0.999600 
False Easting: 500000.000000

False Northing: 0.000000

Latitude of Origin: 0.000000

Linear Unit: Meter

Figure 3 below illustrates the process flow for image procesing and analysis:

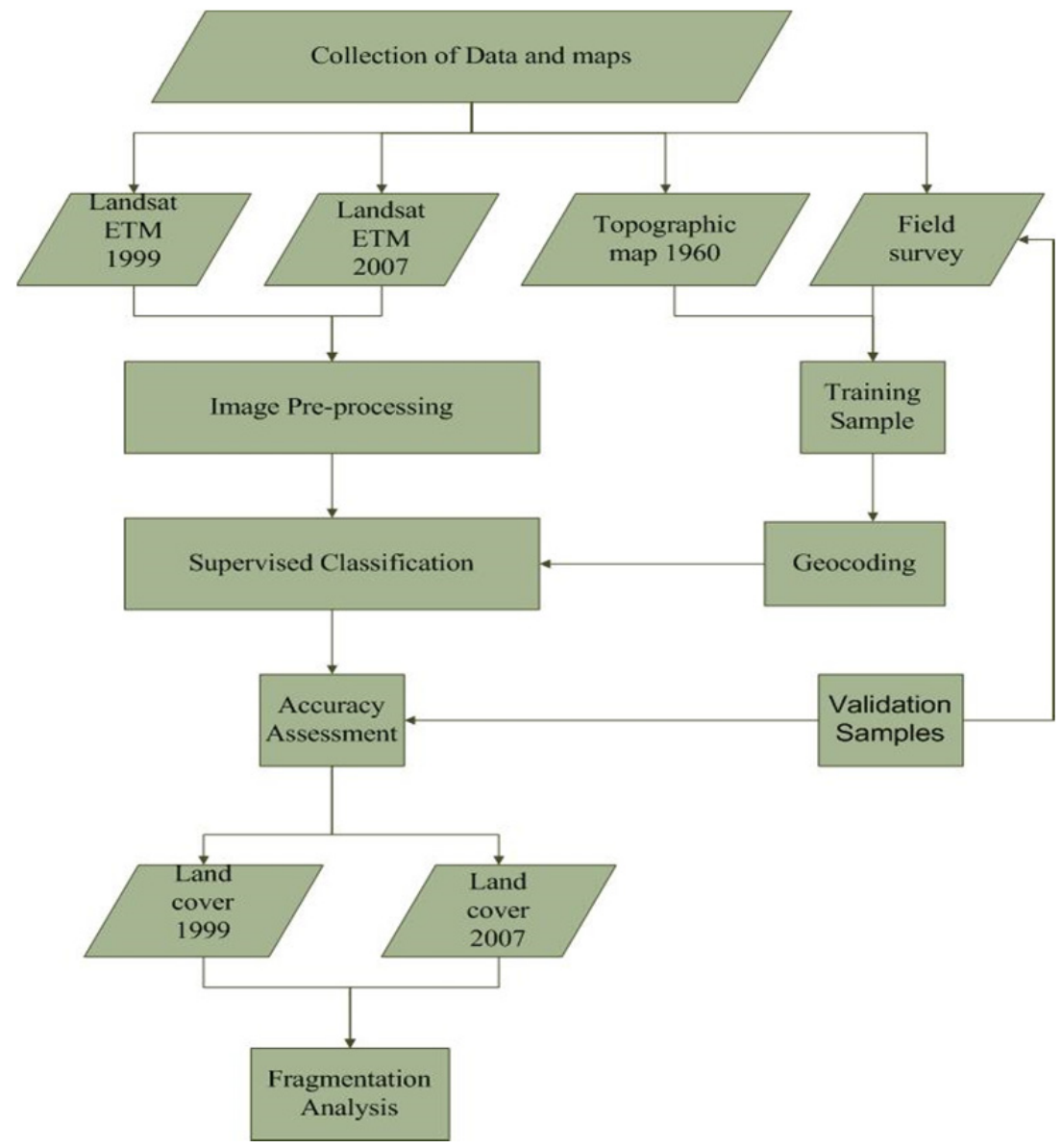

Figure 3. Process flow of the Research Methods

\subsubsection{Image Classification}

The main aim of image classification was to automatically categorize all pixels in an image into land cover classes (Figures 4a and 4b). The classification legend was made based on spectral characteristics of the multi-spectral dataset acquired. Supervised classification was done by following three stages that included training data sets, classification and output. Training samples were taken for each land use/land cover type to be classified in the image. To obtain true representation of the cover classes, spectra signatures were created by repeatedly selecting training samples, assessing and analysing them by either deleting or merging these spectra.

Using ETM bands 4, 3, 2 for both 1999 and 2007 and three true colour composites, a preliminary land cover map was obtained by visual interpretation. This band combination was chosen because it corresponds to the green reflectance of healthy vegetation and one of the most important bands for vegetation discrimination. In addition, it is also useful for soil-boundary and geological boundary mapping as well as responsive to the amount of vegetation biomass present in a scene. These characteristics of the band 4, 3, 2 combinations make it useful for identifying vegetation types, and emphasize soil-crop and land-water contrasts.

Classification was done by using Maximum Likelihood Classifier (MLC). This option evaluated to which class the pixel most likely belonged, based on the pixel value. The landuse and landcover classification was based on a scheme developed by Berry et al (1994) and further highlighted by Anderson et al. (2002), and was used because it suited the savannah ecosystem of the study area with its five cover classes. A classification scheme was 
developed of which the following five land use/land cover classes were distinguished: Bare areas, Built-Up area, Crop and Rangelands, Vegetation, and Water (Table 2). Supervised image classification method was employed to extract thematic information on the land covers from 1999 and 2007 satellite images which resulted in the production of the five (5) LULC types.

Table 2. Definition of LULC Classes

\begin{tabular}{lll}
\hline $\begin{array}{l}\text { LULC Type } \\
\text { Bare }\end{array}$ & $\begin{array}{l}\text { Description } \\
\text { Areas that have neither natural nor } \\
\text { artificial vegetal cover }\end{array}$ & $\begin{array}{l}\text { Subgroups } \\
\text { Sand and soils } \\
\text { Exposed rock surfaces } \\
\text { Gravels }\end{array}$ \\
\hline Built-up & $\begin{array}{l}\text { Area of land covered by houses or other } \\
\text { buildings and increasing in intensity over a } \\
\text { period of time }\end{array}$ & $\begin{array}{l}\text { Settlements } \\
\text { Other infrastructure }\end{array}$ \\
Crop and & $\begin{array}{l}\text { Areas of land used for cultivation and } \\
\text { grassland }\end{array}$ & $\begin{array}{l}\text { Fallow lands } \\
\text { Farmlands }\end{array}$ \\
Rangeland & $\begin{array}{l}\text { Grazing land } \\
\text { Deciduous Forest }\end{array}$ \\
Vegetation & $\begin{array}{l}\text { Areas covered by trees of all ages, plants, } \\
\text { and underbrush covering the large area } \\
\text { within the study area. }\end{array}$ & $\begin{array}{l}\text { Defoliated forest } \\
\text { Sacred groves } \\
\text { Mixed Forest }\end{array}$ \\
& $\begin{array}{l}\text { Shrubs } \\
\text { Rivers } \\
\text { Dams }\end{array}$ \\
\hline
\end{tabular}

(Source: Anderson et al., 2002) part of the year including the dry season Dams

a) 1999 Landsat TM-RGB: 4,3,2 (30 x 30) m

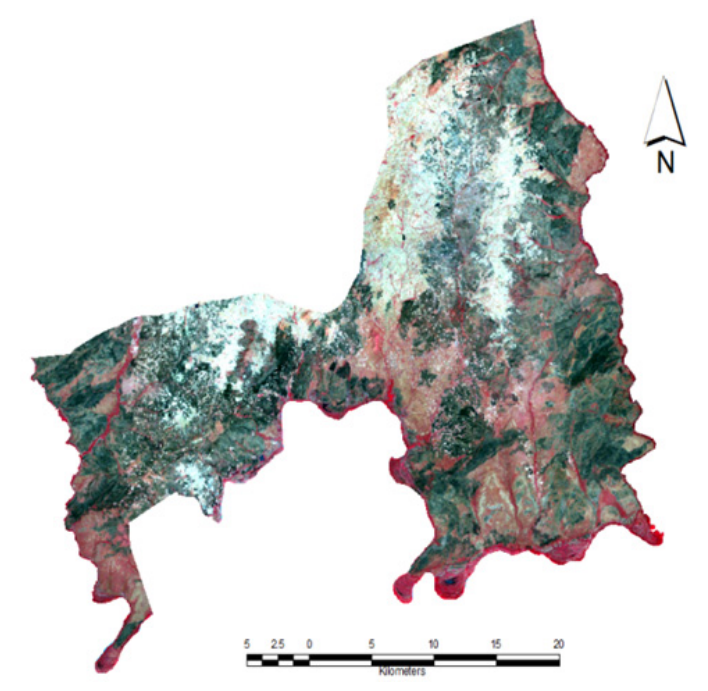

b) 1999 Landsat ETM-RGB, 4,3,2 (30 x 30) m

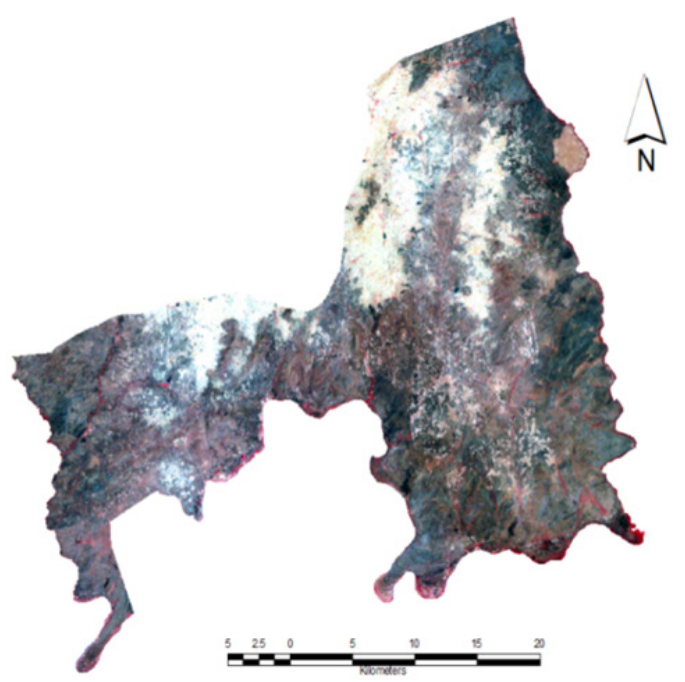

Figure 4. Landsat images of the study areas

\subsubsection{Fragmentation Analysis}

Change in the landscape structure was analysed using FRAGSTATS $\odot$ version 3.3 software in ArcGIS® environment. FRAGSTATS ${ }^{\circledR}$ is a spatial pattern analysis programme for categorical maps that examines landscape characteristics by quantifying the areal extent and spatial configuration of patches and classes within a landscape. FRAGSTATS ${ }^{\circledR}$ is developed to quantify landscape structure with a comprehensive choice of landscape metrics that can be used to describe the characteristics of individual patches, classes of patches, or the entire landscape (Ampofo, 2008; Frimpong, 2011). This was done for the whole of the study area for the two years, 1999 and 2007.The two maps classified were exported in generic binary 8 bit formats in ERDAS 
Imagine ${ }^{\circledR}$ and ran with the FRAGSTATS ${ }^{\circledR}$ program. At the class, the patch and the landscape levels, the following metrics were computed using a cell size of 30 metres: Number of Patches (NP), Patch Density (PD), Largest Patch Index (LPI), Percentage of Landscape (PLAND), Total Class Area (CA) and Mean Patch Size (MPS). Table 3 and Figure 5 illustrate the description of the fragmentation metrics and flowchart of the processes used in the production of the fragmentation metrics respectively.

Table 3. Description of Fragmentation metrics used

\begin{tabular}{|c|c|c|}
\hline $\begin{array}{l}\text { Metric } \\
\text { Number of } \\
\text { Patches (NP) }\end{array}$ & $\begin{array}{l}\text { Description } \\
\text { Number of patches (NP) is equal to total number of patches in each class. }\end{array}$ & $\begin{array}{l}\text { Unit } \\
\text { None }\end{array}$ \\
\hline $\begin{array}{l}\text { Patch Density } \\
\text { (PD) }\end{array}$ & $\begin{array}{l}\text { Patch Density (PD) which measures the NP per } 100 \text { hectares is an index that measures the level of } \\
\text { fragmentation within each class. }\end{array}$ & $\begin{array}{l}\text { Number per } 100 \\
\text { hectares }\end{array}$ \\
\hline $\begin{array}{l}\text { Largest Patch } \\
\text { Index (LPI) }\end{array}$ & $\begin{array}{l}\text { LPI equals the area }\left(\mathrm{m}^{2}\right) \text { of the largest patch of the corresponding patch type divided by total } \\
\text { landscape area }\left(\mathrm{m}^{2}\right) \text {, multiplied by } 100 \text { (to convert to a percentage) or Area of the largest patch in } \\
\text { each class as a percentage of the total landscape area. }\end{array}$ & Percent \\
\hline $\begin{array}{l}\text { Percentage of } \\
\text { Landscape } \\
\text { (PLAND) }\end{array}$ & $\begin{array}{l}\text { PLAND equals the sum of the areas }\left(\mathrm{m}^{2}\right) \text { of all patches of the corresponding patch type, divided by } \\
\text { total landscape area }\left(\mathrm{m}^{2}\right) \text {, multiplied by } 100 \text { (to convert to a percentage) }\end{array}$ & Percent \\
\hline Class Area (CA) & $\begin{array}{l}\text { CA equals the sum of the areas }\left(\mathrm{m}^{2}\right) \text { of all patches of the corresponding patch type, divided by } \\
10,000 \text { (to convert to hectares); that is, total class area. }\end{array}$ & Hectares \\
\hline $\begin{array}{l}\text { Mean Patch Size } \\
\text { (MPS) }\end{array}$ & Average Patch size in each class. & Hectares \\
\hline
\end{tabular}

The indices of LPI, NP and MPS give the estimation of the degree of fragmentation for different land cover types. NP, PLAND and CA in particular is an excellent measure of the fragmentation of a given class within the landscape; since the landscape size is constant, the greater the number of patches, the greater the degree of fragmentation. The comparison of these spatial characterisations therefore reveals the pattern of land cover modification and transformation for the classified images (Southworth and Munroe, 2004).

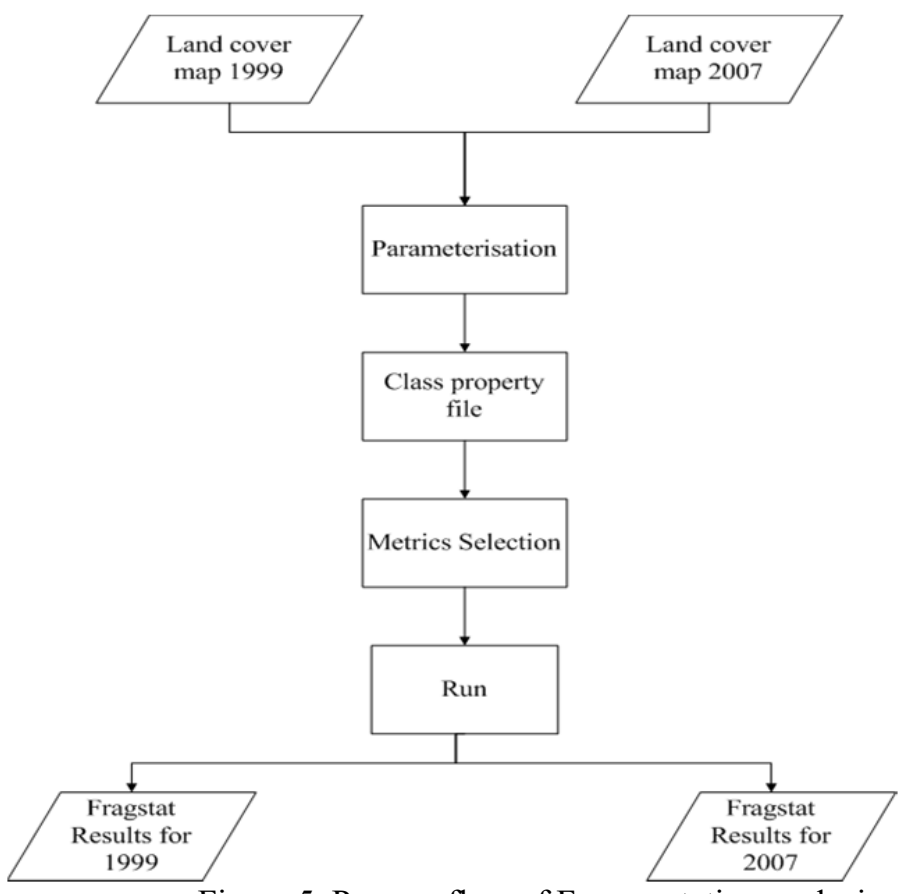

Figure 5. Process flow of Fragmentation analysis 


\section{Results and Discussions}

\subsection{Land Cover Classification and Accuracy Assessment}

Tables 4 and 5 below illustrate the accuracy of the various LULC in the Talensi and Nabdam Districts Land cover maps for 1999 and 2007 (Figures 6 and 7). To observe the changes in the landscape, accuracy assessment of the classified image is an important step in image classification. The quality of a thematic map from a satellite image is determined by its accuracy. An accuracy assessment performed on the Landsat ETM 1999 and 2007 image resulted in an overall accuracy of $63.03 \%$ and $69.39 \%$, respectively.

Table 4. Accuracy Assessment of 1999 Classification

\begin{tabular}{lllllll}
\hline Class Name & $\begin{array}{l}\text { Reference } \\
\text { Total }\end{array}$ & $\begin{array}{l}\text { Classified } \\
\text { Total }\end{array}$ & $\begin{array}{l}\text { Number } \\
\text { of Correct }\end{array}$ & $\begin{array}{l}\text { Producers } \\
\text { Accuracy (\%) }\end{array}$ & $\begin{array}{l}\text { Users } \\
\text { Accuracy (\%) }\end{array}$ & $\begin{array}{l}\text { Kappa } \\
\text { Statistics }\end{array}$ \\
\hline Vegetation & 25 & 10 & 8 & 32 & 80 & 0.7468 \\
Built-up & 43 & 39 & 34 & 79.07 & 87.18 & 0.7993 \\
Bare Areas & 28 & 49 & 25 & 89.29 & 51.02 & 0.3595 \\
Crop and & 19 & 8 & 6 & 31.58 & 75 & 0.7025 \\
$\begin{array}{l}\text { Rangeland } \\
\text { Water }\end{array}$ & 4 & 2 & 2 & 50 & 100 & 1 \\
Total & 119 & 119 & 87 & $\begin{array}{l}\text { Overall } \\
\text { Accuracy } 63.03 \%\end{array}$ & Classification & Overall \\
& & & & & & Kappa \\
& & & & & & Statistics \\
& & & & & & 0.5107 \\
\hline
\end{tabular}

Table 5. Accuracy Assessment for 2007 Classification

\begin{tabular}{|c|c|c|c|c|c|c|}
\hline Class Name & $\begin{array}{l}\text { Reference } \\
\text { Total }\end{array}$ & $\begin{array}{l}\text { Classified } \\
\text { Total }\end{array}$ & $\begin{array}{l}\text { Number of } \\
\text { Correct }\end{array}$ & $\begin{array}{l}\text { Producers } \\
\text { Accuracy (\%) }\end{array}$ & $\begin{array}{l}\text { Users } \\
\text { Accuracy } \\
(\%)\end{array}$ & Kappa Statistics \\
\hline Vegetation & 28 & 14 & 13 & 46.43 & 92.86 & 0.9066 \\
\hline Built-up & 41 & 54 & 35 & 85.37 & 64.81 & 0.4632 \\
\hline Bare Areas & 27 & 22 & 16 & 59.26 & 72.73 & 0.6472 \\
\hline $\begin{array}{l}\text { Crop and } \\
\text { rangeland }\end{array}$ & 19 & 16 & 13 & 68.42 & 81.25 & 0.7769 \\
\hline Water & 4 & 2 & 2 & 50 & 100 & 1.0000 \\
\hline \multirow[t]{2}{*}{ Total } & 119 & 119 & 79 & & & \\
\hline & & & & Overall & Classification & Overall Kappa \\
\hline
\end{tabular}

\subsection{Land Use/Land Cover Analysis (LULC)}

\subsubsection{LULC Analysis in 1999}

The spatial extent of the 1999 LULC map after the Supervised Classification yielded five (5) land cover classes (Figures 6) with the Bare areas occupying the highest percentage (49,909.9 ha, 51.62\%). The Bare area is fairly distributed in the map with the highest concentration around Tula and Sekoti in the north-east and south-east, respectively (Fig. 6). The next LULC class with the highest area coverage is the vegetation $(20,247.8$ ha, 20.94\%), which is concentrated around the south-eastern and south-western parts of the area with very small patches around the northern part of the study area. Crop and rangelands (11,690.2 ha, 12.09\%) are the next in terms of area coverage and are mainly distributed around the central part of the study area and areas closer to the White Volta River to the southern boundary line. The Built-up area has 11,439.7 ha (11.83\%) and its area coverage is concentrated at the western and northern part of the study area with some few patches around the southern and central areas. The last is water, covering 3396.78 ha $(3.5 \%)$ which is also distributed fairly in the study area except the north where there is the Tongo hilly terrain. 


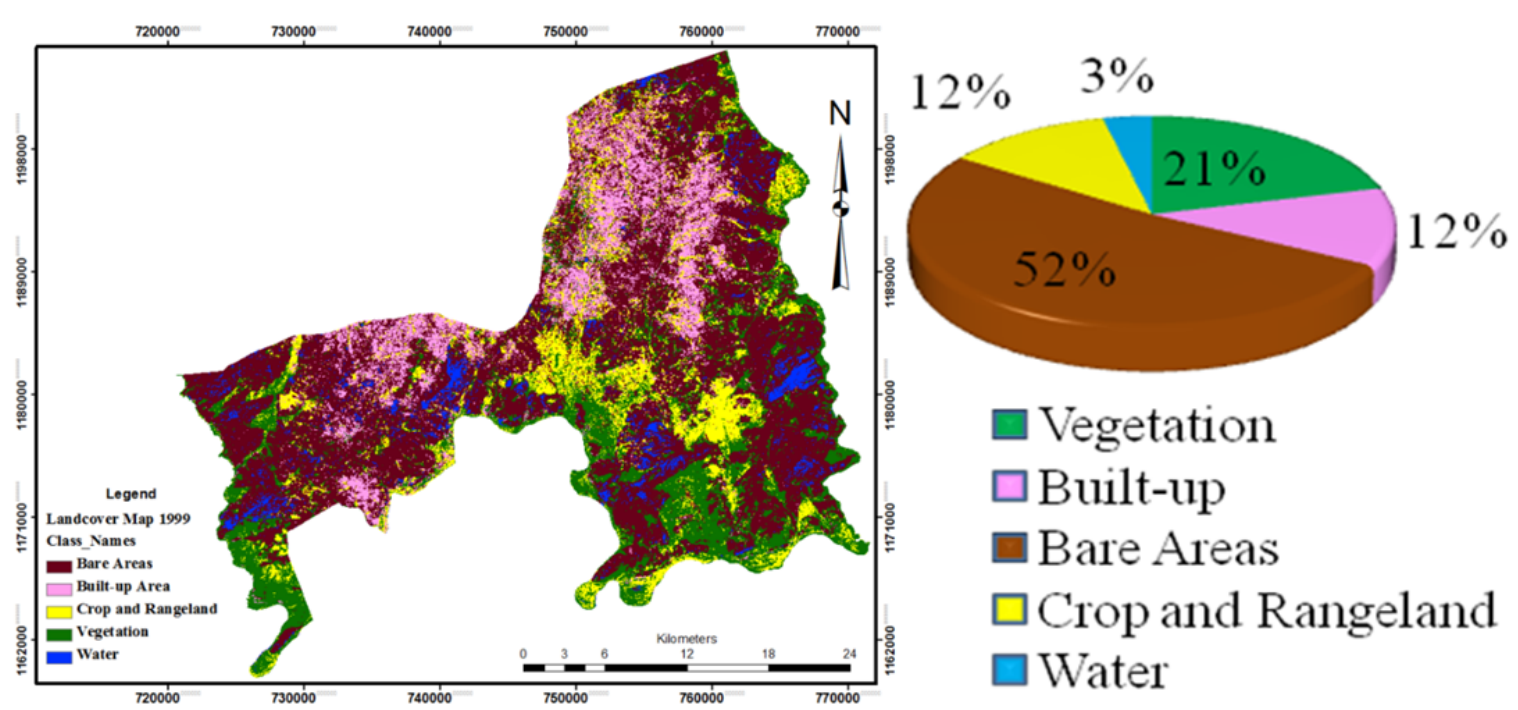

Figure 6. LULC map for 1999 and its cover proportion

\subsubsection{LULC Analysis in 2007}

The Supervised classification procedures used for the 2007 image yielded five basic land cover types with Bare Area having the largest area coverage of 33,310.89 ha (35\%) as compared to the other LULC classes and largely concentrated around the southern and south-eastern part of the study area, with a few around north and western part of the area (Figure 7). Built-up areas constituted the second highest cover type with 24,566.94 ha (25\%) and occurred mainly around the northern and western parts, with some few patches at southern and eastern zones. Vegetation, which comes next with $22,882.77$ ha (24\%), is mainly scattered within the study area with some regular patches at the western part of the study area. Crop and rangeland (14,541.84 ha, $15 \%)$ is also scattered across the study area and mixes with patches of vegetation but concentrated at the western and central parts of the study area. Water can be said to be fairly distributed, covering $1,381.86$ ha (1.0 \%) of the study area.

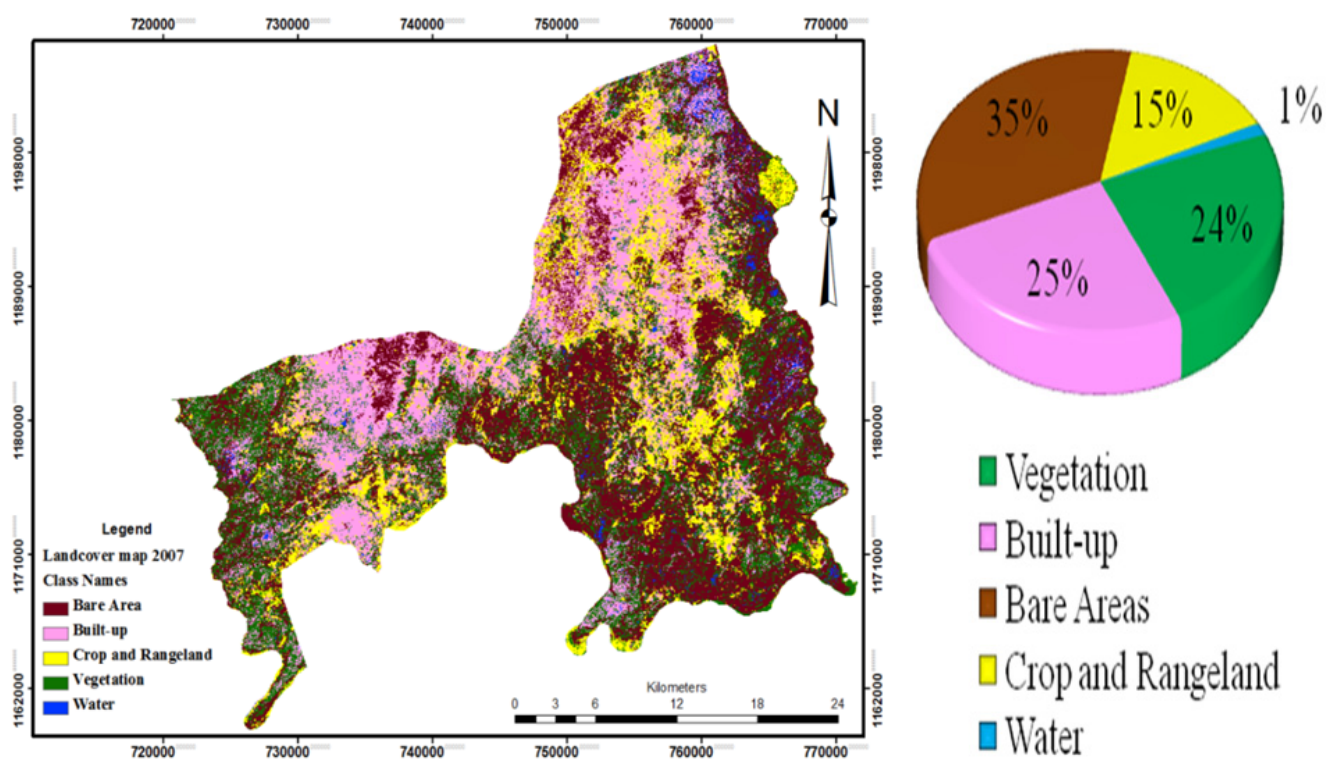

Figure 7. LULC map for 2007 and its cover proportion

\subsubsection{Spatial Extent of LULC after Classification}

The majority of the LULC changes took place within the Built-up and Bare areas while the remaining classes experienced slight changes over the 8-year period under study. Although, Bare areas covered the highest proportion of the land area in 1999 as in 2007, the results show that much of the Bare areas have been converted 
into Built-up areas due to settlement expansion. In 2007, crop and rangeland increased by 2,851 ha (20\%) which corresponds to the increment in the Built-up areas; i.e., demands for land for housing and consequent settlement expansion as well as parallel demand for agricultural land. Table 6 and Figure 8 show LULC proportions for 1999 and 2007.

Table 6. Proportion of the various LULC types

\begin{tabular}{lllll}
\hline Class Name & \multicolumn{2}{l}{ Area (ha) } & \multicolumn{2}{c}{ Area (\%) } \\
& 1999 & 2007 & 1999 & 2007 \\
\hline Vegetation & 20247.8 & 22882.77 & 20.94 & 23.66 \\
Built-up & 11439.7 & 24566.94 & 11.83 & 25.40 \\
Bare Areas & 49909.9 & 33310.89 & 51.62 & 34.45 \\
Agriculture & 11690.2 & 14541.84 & 12.09 & 15.04 \\
Water & 3396.78 & 1381.86 & 3.51 & 1.42 \\
Total & 96684.3 & 96684.3 & 100 & 100 \\
\hline
\end{tabular}

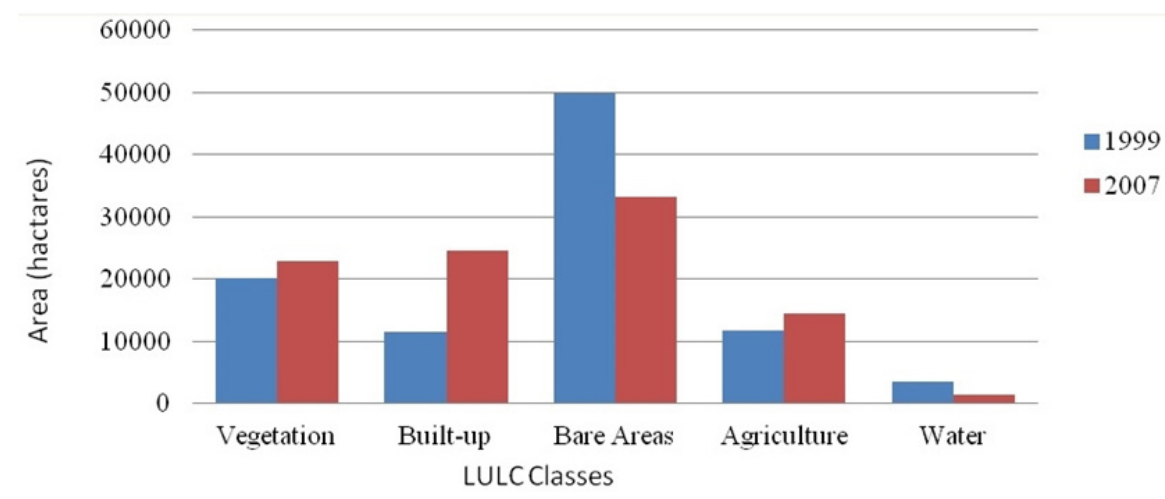

Figure 8. Graph of LULC Proportions in 1999 and 2007

\subsection{Fragmentation Statistics of LULC Types within the Talensi and Nabdam Districts}

The computed fragmentation statistics of the LULC types showed that significant changes in the structure of the landscape have occurred. The general pattern reveals a continuous change in the landscape structure which is revealed by the changing landscape metrics. From Table 6, it can be observed that within the 8-year period, the number of patches (NP) for all classes increased, with the Crop and rangeland increasing from 13,871 to 37,543 representing a change of about 46.04\%. The number of patches for vegetation increased by $17,168(20.69 \%)$ for the same period. The Patch Density (PD), which measures the number of Patches per 100 hectares, is an index which measures the level of fragmentation within each class. The higher the PD, the higher the level of fragmentation within each class and vice versa, and this increased for all classes from 1999 to 2007. However, the largest patch index which measures area of the largest patch in each class as a percentage of the total landscape area increased for only built-up area. This means more patches have been created and that is also reflected in the patch density of the various classes within the 8 years in the vegetation, crop and rangeland and bare areas (Table 7).

Table 7. Fragmentation Statistics for the various LULC types

\begin{tabular}{lllll}
\hline Metric & LULC Type & 1999 & 2007 & Difference \\
\hline Class Area (CA) & Forest & 20,251 & 22,886 & 2,635 \\
& Built-up area & 11,441 & 24,568 & 13,127 \\
& Bare Area & 49,910 & 33,312 & $-16,599$ \\
& Cropland & 11,692 & 14,543 & 2,851 \\
\hline Percentage Landscape & Forest & 8.6 & 9.8 & 1.2 \\
(PLAND) & Built-up area & 4.9 & 10.5 & 5.6 \\
& Bare Area & 21.3 & 14.2 & -7.1 \\
& cropland & 5.0 & 6.2 & 1.2 \\
\hline Number of Patches & Forest & 32,902 & 50,070 & $17,168.0$
\end{tabular}




\begin{tabular}{lllll} 
(NP) & Built-up area & 20,238 & 36,937 & $16,699.0$ \\
& Bare Area & 13,871 & 37,543 & $23,672.0$ \\
& cropland & 29,848 & 34,527 & $4,679.0$ \\
\hline Patch Density & Forest & 14 & 21 & 7 \\
(PD) & Built-up area & 9 & 16 & 7 \\
& Bare Area & 6 & 16 & 10 \\
& cropland & 13 & 15 & 2.0 \\
\hline Largest Patch Index (LPI) & Forest & 0.5 & 0.03 & -0.47 \\
& Built-up area & 0.1 & 0.76 & 0.24 \\
& Bare Area & 2.0 & 0.70 & -1.30 \\
& cropland & 0.1 & 0.03 & -0.07 \\
\hline Mean Patch Size & Forest & 0.62 & 0.46 & -0.16 \\
(MPS) & Built-up area & 0.57 & 0.67 & 0.10 \\
& Bare Area & 3.60 & 0.89 & -2.71 \\
& cropland & 0.39 & 0.42 & 0.03 \\
\hline
\end{tabular}

\subsubsection{Class Area (CA), 1999 to 2007}

Table 8 below shows that Class area (CA) of forest, Built-up, and Crop and rangelands increased by 2,635 ha, 1,327 ha and 2,852 ha, respectively, whilst Bare areas decreased by 16,599 ha from 1999 to 2007 .

Table 8. Class Area metric from 1999 to 2007 for the various LULC types

\begin{tabular}{lllll}
\hline Class Metric & LULC types & 1999 & 2007 & Difference \\
\hline & Forest & 20,251 & 22,886 & 2,635 \\
& Built-up area & 11,441 & 24,568 & 13,127 \\
Class Area (ha ) & Bare Area & 49,910 & 33,312 & $-16,599$ \\
& Cropland & 11,692 & 14,543 & 2,852 \\
\hline
\end{tabular}

\subsubsection{Percentage of Landscape (PLAND), 1999 to 2007}

From Table 9, Percentage Landscape (PLAND) for only built-up increased, while the PLAND for bare area decreased considerably over the period of the study (Table 9). However, PLAND for crop and rangeland and vegetation experienced a slight increment within the period of study.

Table 9. PLAND metric for 1999 and 2007 for the various LULC types

\begin{tabular}{lllll}
\hline Metric & LULC Type & 1999 & 2007 & Difference \\
\hline & Forest & 8.6 & 9.8 & 1.1 \\
& Built-up area & 4.9 & 10.5 & 5.6 \\
Percentage Landscape (PLAND) & Bare Area & 21.3 & 14.2 & -7.1 \\
& Cropland & 5.0 & 6.2 & 1.2 \\
\hline
\end{tabular}

\subsubsection{Patch Density (PD), 1999 to 2007}

Table 10 below illustrates the class level metrics for PD of the various LULC classes. PD for bare area, forest and built-up areas witnessed a significant increment; thus from 6,14 and 9 patches per 100 hectares in 1999 to 16, 21 and 16 patches per 100 hectares in 2007 for bare areas, forest and Built-up areas, respectively. Cropland increased by two (2) patches per every 100 hectares over the 8 -year period.

Table 10. Patch Density for 1999 and 2007 for the various LULC types

\begin{tabular}{lllll}
\hline Metric & LULC Type & 1999 & 2007 & Difference \\
\hline & Forest & 14 & 21 & 7.0 \\
& Built-up area & 9 & 16 & 7.0 \\
Patch Density (Patches/100ha) & Bare Area & 6 & 16 & 10.0 \\
& cropland & 13 & 15 & 2.0 \\
\hline
\end{tabular}




\subsubsection{Largest Patch Index (LPI), 1999 to 2007}

Table 11 shows that LPI for forest, bare area and cropland decreased over the 8 year period while built-up area increased from 1999 to 2007. This indicates that, Bare area and Croplands have undergone further fragmentation into smaller patches within the 8-year period.

Table 11. Largest Patch Index for 1999 and 2007 for the various LULC types

\begin{tabular}{lllll}
\hline Metric & LULC Type & 1999 & 2007 & Difference \\
\hline \multirow{4}{*}{ Largest Patch Index (LPI) } & Forest & 0.5 & 0.03 & -0.47 \\
& Built-up area & 0.1 & 0.76 & 0.62 \\
& Bare Area & 2.0 & 0.70 & -1.30 \\
& cropland & 0.1 & 0.03 & -0.07 \\
\hline
\end{tabular}

\subsubsection{Number of Patches (NP), 1999 to 2007}

The Number of Patches (NP) increased across all LULC, but a significant increment was observed with Bare Areas having the highest number of patches followed by Forest and Built-up areas and Cropland having the least increment. The increment order are 23,672 ha (63\%), 17,168 ha (34\%) 16,699ha (45\%) and 4,679 ha (14\%) for Bare areas, Forest, Built-up area and Cropland, respectively (Table 12).

Table 12. Number of Patch metric for the various LULC types

\begin{tabular}{lllll}
\hline Metric & LULC Type & 1999 & 2007 & Difference \\
\hline & Forest & 32,902 & 50,070 & $17,168.0$ \\
& Built-up area & 20,238 & 36,937 & $16,699.0$ \\
Number of Patches (NP) & Bare Area & 13,871 & 37,543 & $23,672.0$ \\
& Cropland & 29,848 & 34,527 & $4,679.0$ \\
\hline
\end{tabular}

\subsubsection{Mean Patch Size}

The Mean Patch Size (MPS) of the areas covered with vegetation and bare areas observed a decrease in the Mean Patch Size, whereas Built-up area witnessed a small increment (Table 13). However, this change in the Crop and rangeland was insignificant. This implies that, Vegetation and Bare areas are undergoing conversion and fragmentation into Cropland and Built-up area.

Table 13. Mean Patch Size for the various LULC types

\begin{tabular}{lllll}
\hline Metric & LULC & 1999 & 2007 & Difference \\
\hline \multirow{3}{*}{ Mean Patch Size (MPS) } & Vegetation & 0.62 & 0.46 & -0.2 \\
& Built-up area & 0.57 & 0.67 & 0.1 \\
& Bare Area & 3.60 & 0.89 & -2.7 \\
& Cropland & 0.39 & 0.42 & 0.0 \\
\hline
\end{tabular}

\subsection{LULC Mapping and Changes}

The land cover maps (Figures 6 and 7) show the changes that have occurred in the Talensi and Nabdam Districts since 1999. The 1999 and 2007 classified image produced an accuracy of $63.03 \%$ and $66.39 \%$ with a Kappa Statistic of 0.5107 and 0.5530 respectively (Table 4 and 5). Crop and rangelands had the highest user's accuracy of $91 \%$ with Kappa statistic of 0.85 , while bare area had the highest producer's accuracy of $71 \%$ with the lowest kappa of 0.40. A widely used, acceptable accuracy, which is accepted in LULC classification is $85 \%$ (Anderson et al., 2002). The low overall accuracy level is explained in the use of dry season images in mapping vegetation and agricultural cover. For example, a maize field or grassland in the dry season is very bare because there is no chlorophyll matter in the plant stocks which leads to misclassification (Ampofo et al., 2015).

\subsection{Landscape Fragmentation Analysis}

From 1999 to 2007, increase in vegetation areas was relatively small as compared to the other LULC types within the 8-year period of study, and this resulted in the increase of their Class Area (CA) (Table 6). However, 
the Number of Patches (NP) and the Patch Density (PD) for vegetation increased significantly, reflecting increased socio-economic activities that are carried out in the areas covered with vegetation, mainly illegal mining, agricultural expansion, settlement expansion and fuel wood harvesting. These activities, for instance, illegal small-scale mining, which require the removal of the top soil, was observed to be taking place under the forest trees. These activities explain the decrease in the Mean Patch Size (MPS) for Vegetation areas.

The CA of Bare areas decreased within the landscape from 1999 to 2007 by being converted to Built-up areas. This is proportional to PLAND and CA, but PD and NP also increased over the period which is attributable to its conversion to built-up area. The trooping of inhabitants to the study area for socio-economic purposes has resulted in built-up expansion over the 8 years. The CA and the NP of croplands increased considerably over the 8-year period. The increase of croplands within the landscape is due to the population expansion in the study area. Largest Patch Index (LPI) reduced, whereas Mean Patch Size (MPS) of crop and rangelands remained the same from 1999 to 2007, which is an indication that the areas covered with vegetation are being fragmented into crop and rangelands. The LPI for the Built-up area increased considerably within the same period, whilst Largest Patch Index for the other LULC types decreased. This suggests that Built-up is increasingly becoming a dominant factor within the Landscape. The expansion is mainly at the northern part of the study area bordering to the Bolgatanga Municipality, as well as the western area with some few patches around the south-eastern part.

Over short periods (decades or months), natural disturbances, such as forest fires, floods, landslides and windstorms modify and fragment landscapes. In addition, landscapes are naturally fragmented by mountain ridges, rivers and roads (Laverty and Gibbs, 2007). However, landscape fragmentation in the Talensi and Nabdam Districts appears to have been triggered by its endowment with natural resources, such as mineral deposits. The informal sector of the economy of the districts dominates and therefore, there is high dependence on natural resources. As such, subsistence farming, illegal small-scale mining, firewood harvesting as well as charcoal burning are prevalent economic activities in the area. From Table 7, it can be observed that vegetation areas have increased over the period. However, this corresponded to an increase in the level of fragmentation, as depicted by the NP, PD and MPS.

The prevailing land tenure system contributes to the fragmentation of crop and rangelands, as land is constantly fragmented and given to individuals for farming and other purposes, including development of transportation tracks which eventually develop into roads (Seiler and Munroe, 2006). Once a landscape has been fragmented, the size of the remaining patches becomes a critical factor in determining the number and type of faunal species that can survive within them. For all faunal species, large or small, that cannot or will not cross or leave a patch, all requirements to complete their life cycle must be met within the patch; from finding food to mating partners. This is especially important for species with complex life cycles, each with distinct habitat requirements (Laverty and Gibbs, 2007). Fragmentation of landscapes also inhibits modern agriculture, as mechanised farming requires some reasonable patch of land which has not undergone fragmentation for operation.

\section{Conclusion}

The objective of this study was to analyse the landscape fragmentation of Talensi and Nabdam Districts in the Upper East Region using remotely sensed data and GIS based techniques. The relationships between anthropogenic activities and LULC types as well as the fragmentation of these LULC were investigated and various thematic maps were developed. The main LULC types identified in the Talensi and Nabdam Districts are coded into Bare areas, Vegetation, Built-up areas, Crop and rangeland, and water. The analyses revealed that the composition and configuration of the LULC within the catchment had changed significantly over the 8-year period of study. The Bare area loss and fragmented forest within the area of study could be explained by the LULC conversion for settlement purposes. This loss is attributed to the Built-up expansion in response to population increase. The studies have revealed that there have been significant changes in the LULC types as well as the natural landscape in the Talensi and Nabdam Districts.

\section{References}

Alves, D. S., \& Skole, D. L. (1996). Characterizing land cover dynamics using multi-temporal imagery. International Journal of Remote Sensing, 17(4), 835-839.

Ampofo, S. (2008). Agricultural expansion and landcover change in the Volta gorge area, Ghana., University of Twente, Enchede.

Ampofo, S., Ampadu, B., \& Abanyie, S. K. (2015). Landcover change patterns in the Volta gorge area, Ghana: Interpretations from sattelite imagery. Journal of Natural sciences Research, 5(4), 71- 82.

Anderson, J. R., Hardy, E. E., Roach, J. T., \& WItmer, R. E. (2002). A Land use and Land Cover Classification System for use with Remote Sensor Data. Sioux falls) 
Berry, M. W., Hazen, B. C., MacIntyre, R. L., \& Flamm, R. O. (1996). LUCAS: A system for monitoring land-use change [Electronic Version]. IEEE Computaional Science and Engineering,

Bizimana, C., Nieuwoudt, W. L., \& Ferrer, S. R. D. (2004). Farm size, land fragmentation and economic efficiency in Southern Rwanda. Agrekon, 43(2).

Dwivedi, R. S., \& Sreenivas, K. (2005). Land-use/land-cover change analysis in part of Ethiopia using Landsat Thematic Mapper data" International Journal of Remote Sensing 26(7), 1285-1287.

Fahrig, L. (2003). Effects of habitat fragmentation on biodiversity Annual Review of Ecology, Evolution, and Systematics, 34, 487-515.

Frimpong, A. (2011). Application of Remote Sensing and GIS for Forest Cover Change Detection (A case study of Owabi Catchment in Kumasi, Ghana).

Hong, S. K. (1999). Causes and consequence of landscape fragmentation and changing disturbance by socio-economic development in mountain landscape system in South Korea Journal of Environmental Science, 11(2), 181-187.

Honnay, O., Piessens, K., Van Landuyt, W., Hermy, M., \& Gulinck, H. (2003). Satellite based land use and landscape complexity indices as predictors for regional plant species diversity. Landscape and Urban planning, 63, 241-250.

Laverty, M. F., \& Gibbs, J. P. ( 2007). Ecosystem Loss and Fragmentation. Lessons in Conservation (I), $72-96$.

Liu, Y. L., Jiao, L. M., \& Liu, Y. F. (2010). Land use data generalisation indices based on scale and landscape pattern The International Archives of the Photogrammetry, Remote Sensing and Spatial Information Sciences, 38(2).

Parent, J., Civco, D., \& Hurd, J. (2007). Simulating future forest fragmentation in a Connecticut region undergoing suburbanisation. Paper presented at the ASPRS 2007 Annual conference.

Seiler, A., \& Folkesson, L. (Eds.). (2006). Habitat fragmentation due to transportation infrastructure (Vol. VTI Rapport 530 A). Stockholm: VTI Publications.

Southworth, J. D., \& Munroe (2004). Land cover change and landscape fragmentation-comparing the utility of continuous and discrete analyses for a western Honduras region. Agriculture, Ecosystems and Environment, 101, 185-205.

Talensi-Nabdam District Planning Coordinating Unit, (D.P.C.U) (2011). Talensi-Nabdam District Profile. Tongo: Talensi-Nabdam District Assembly.

Talensi-Nabdam District Planning Coordinating Unit, (D.P.C.U) (2012). Talensi-Nabdam District Strategic Environmrntal Assessment (SEA). Tongo: Talensi-Nabdam District Assembly.

Vogt, P., Riiters, K. H., Estreguil, C., Kozak, J., Wade, T. G., \& Wickham, J. D. (2007). Mapping spatial patterns with morphological image processing. Landscape Ecology, 22, 171-177.

\section{Copyrights}

Copyright for this article is retained by the author(s), with first publication rights granted to the journal.

This is an open-access article distributed under the terms and conditions of the Creative Commons Attribution license (http://creativecommons.org/licenses/by/3.0/). 